\title{
MEMAHAMI FUNGSI GOSIP DALAM MASYARAKAT MELALUI FILM PENDEK "TILIK"
}

\author{
Fakhirah Inayaturrobbani \\ Center for Indigenous and Cultural Psychology (CICP) \\ Psikologi, Fakultas Psikologi, Universitas Gadjah Mada \\ fakhirah.inayaturrob@mail.ugm.ac.id
}

\begin{abstract}
Abstrak: Gosip merupakan fenomena sehari-hari yang sering terabaikan dalam pengkajian ilmiah. Oleh karena itu, penelitian ini bertujuan untuk menganalisis perilaku gosip dalam film Tilik menggunakan teori psikologi evolusi Self-Concept Enhancing Tactician (SCENT) model. Teori model SCENT menjelaskan bahwa seseorang mencari dan mengevaluasi rumor dengan tiga tujuan yaitu pengembangan diri, promosi diri dan perlindungan diri. Penelitian ini menggunakan pendekatan kualitatif interpretatif (Denzin) untuk menjelaskan dinamika fungsi gosip dalam film Tilik. Hasil penelitian menunjukkan bahwa pelaku gosip negatif menggunakan gosip sebagai promosi dan perlindungan diri. Apabila gosip dipersepsi oleh penggosip sebagai perbandingan ke bawah, kesempatan untuk promosi diri lebih tinggi. Sementara itu, apabila gosip dianggap sebagai ancaman, individu akan melindungi diri dengan berbagai c ara. Promosi diri para pelaku gosip melibatkan emosi bangga sementara itu fungsi perlindungan diri melibatkan emosi takut. Hasil penelitian ini menambah wawasan bagaimana fungsi gosip di masyarakat.
\end{abstract}

Kata Kunci: Gosip, SCENT Model, pengembangan diri, promosi diri, perlindungan diri, Tilik, Denzin

\section{UNDERSTANDING GOSSIP FUNCTION IN SOCIETY THROUGH “TILIK" SHORT MOVIE}

\begin{abstract}
Gossip is a daily phenomenon but largely neglected in the scientific literature. Therefore, this study aims to analyze the dynamics of gossip activities in the Tilik short movie. The theory used is the Self-Concept Enhancing Tactician (SCENT) model, which shows that a person is looking for information and evaluating that information with three objectives: self-empowerment, self-promotion, and selfprotection. The method used in this study was an interpretative qualitative approach (Denzin) to explain the function of gossip in Tilik movie. The result of this study indicates that gossip has two prominent functions: self-promotion and selfprotection. If the gossip is perceived by the gossipmongers as a downward comparison, the chance for self-promotion is higher. Meanwhile, if it is considered as a threat, individuals will protect themselves in various ways. Self-promotion involves the emotion of pride and self-protection involves the emotion of fear. This research is expected to add insight into how gossip is used in society.
\end{abstract}

Keywords: Gossip, SCENT Model, self-development, self-promotion, selfprotection, Tilik, Denzin 


\section{Pendahuluan}

Sebuah film pendek berjudul "TILIK" (durasi 32 menit) menjadi sangat populer diperbincangkan masyarakat sejak diunggah pada kanal berbagi YouTube pada 17 Agustus 2020. Judul Tilik diambil dari Bahasa Jawa yang bermakna "Menjenguk". Setidaknya saat artikel ini ditulis (15 September 2020) film tilik telah ditonton 32 juta kali. Film Tilik merepresentasikan potret masyarakat pedesaan yang mengambil latar belakang budaya di sebuah desa di Yogyakarta. Menariknya, Film Tilik, yang lolos kurasi dana istimewa Dinas Kebudayaan Provinsi Daerah Istimewa Yogyakarta pada 2018 ini, mengangkat tema gosip yang sangat dekat dengan masyarakat (Kintoko, 2020). Lebih spesifik Tilik berkisah tentang aktivitas gosip rombongan ibu-ibu yang sedang dalam perjalanan menjenguk Ibu Lurah dengan menggunakan truk.

Fenomena gosip sangat dekat dengan kehidupan sehari-hari yang bersifat multikultural (pada berbagai budaya). Sebuah penelitian di Selandia Baru menunjukkan bahwa perempuan seringkali bergosip soal rumah tangga dan perselingkuhan (Jones, 1980). Tidak hanya itu, penggunaan gosip di perkotaan maupun di pedesaan cenderung menunjukkan pola yang sama yaitu berkaitan dengan persaingan reputasi sosial (Merry, 1984). Hal ini menunjukkan fenomena gosip yang diangkat pada film Tilik sebuah representasi sosial yang jamak ditemui dalam budaya apapun.

Gosip yang dapat didefinisikan sebagai pembicaraan evaluatif positif maupun negatif terhadap seseorang yang tidak hadir saat pembicaraan tersebut berlangsung (Foster, 2004) memiliki beberapa fungsi. Dalam percakapan sehari-hari, fungsi gosip ditujukan untuk mensosialisasikan norma kelompok, menghukum mereka yang melanggar norma kelompok (Grosser et al.,
2010), melindungi keanggotaan kelompok yang terancam diserang oleh orang lain (Beersma \& Van Kleef, 2011; Feinberg et al., 2012; Kniffin \& Wilson, 2005) menjaga reputasi dan pengaruh (Sommerfeld et al., 2007), dan membangun ikatan sosial dalam suatu kelompok (Bosson et al., 2006; Dunbar, 2004)

Pada saat yang sama, para pelaku gosip memiliki kecenderungan untuk melakukan perbandingan dan evaluasi sosial. Aktivitas bergosip dapat bersifat fungsional untuk sebagian individu karena individu membutuhkan informasi evaluatif tentang orang lain guna mengevaluasi diri mereka sendiri. Evaluasi diri melalui perbandingan sosial seringkali diperlukan guna melakukan penyesuaian diri dengan norma kelompok (Festinger, 1954; Sedikides \& Skowronski, 2000; Sedikides \& Strube, 1997). Meskipun demikian, literatur mengenai perbandingan sosial seringkali tidak mengikutsertakan gosip sebagian bagian dari mencari informasi tentang orang lain untuk melakukan evaluasi diri dan sosial (Wert \& Salovey, 2004). Padahal, aktivitas gosip adalah cara yang sangat dekat dengan masyarakat dalam mendapatkan informasi perbandingan sosial dengan orang yang menjadi target perbandingan daripada bertemu secara langsung dengan sang target (Suls, 1977; Wert \& Salovey, 2004). Oleh karena itu, dalam artikel ini, peneliti memfokuskan pada aktivitas gosip sebagai bagian dari aktivitas evaluasi diri terhadap sosial, yang jarang diteliti.

Penelitian ini menggunakan model teori Self-Concept Enhancing Tactician (SCENT) (Sedikides \& Strube, 1997) yang fokus pada taktik untuk meningkatkan konsep diri. Teori SCENT mendasari teorinya dengan asumsi bahwa manusia melakukan aktivitas tertentu, termasuk bergosip, dengan tujuan untuk menaikkan gambaran dan konsep diri pribadi maupun sosial di masyarakat. Dalam konteks gosip, 
individu menerima gosip positif dan/atau negatif dengan tiga tujuan, yaitu pengembangan diri (self-improvement), promosi diri (self-promotion), atau perlindungan diri (self protection).

Secara umum, nilai evaluasi diri seseorang dari suatu gosip tergantung pada jenis gosipnya. SCENT menjelaskan bahwa gosip yang positif akan menjadi menghasilkan pengembangan diri (selfimprovement) yang lebih tinggi pada seorang individu, sementara individu yang terlibat dan menerima gosip negatif cenderung meningkatkan nilai promosi diri (self promotion) dan perlindungan diri (self protection) daripada nilai pengembangan diri (self-improvement). Dengan menggunakan teori SCENT tersebut, penelitian ini melihat bagaimana fungsi gosip dalam masyarakat melalui film Tilik tersebut.

\section{Landasan Teori}

Teori Model Self-Concept Enhancing Tactician (SCENT)

Menurut model Self-Concept

Enhancing Tactician (SCENT), mekanisme evaluasi diri merupakan aspek fundamental dari kehidupan manusia. Manusia termotivasi untuk terus memperbarui presentasi dan deskripsi diri mereka, baik secara pribadi maupun sosial, dengan tujuan akhir mempertahankan konsep diri yang positif (Sedikides \& Gregg, 2008; Sedikides \& Strube, 1997). Model SCENT mengasumsikan bahwa proses evaluasi diri tidak selalu membutuhkan informasi yang akurat sebaliknya individu cenderung memilih informasi-informasi yang sesuai dengan dirinya untuk melindungi konsep diri yang dianggap positif (Sedikides \& Strube, 1997)

Mengapa individu cenderung bias saat melakukan pemilihan informasi dalam proses evaluasi diri? Perasaan positif tentang diri sangat penting dalam kesehatan mental individual sebab konsep diri yang positif berfungsi untuk membantu dan melindungi individu dari kecemasan dan perilaku yang merusak diri (Pyszczynski et al., 2004). Individu dapat meningkatkan konsep diri positif mereka secara langsung melalui promosi diri, seperti melakukan pujian terhadap diri sendiri, perbandingan sosial ke bawah, dan menghindari perbandingan sosial yang tidak menguntungkan (Sedikides \& Strube, 1997).

Motivasi untuk mengevaluasi diri akan membuat individu secara aktif maupun pasif mengumpulkan informasi yang dibutuhkan untuk proses evaluasi, salah satunya adalah melalui gosip. Evaluasi diri dimotivasi oleh fungsi pengembangan diri (selfimprovement), promosi diri (self-promotion) dan melindungi diri (self-protection). Gosip tentang perilaku dan barang-barang orang lain dapat berfungsi sebagai pengembangan diri (self-improvement) apabila gosip digunakan untuk mengakses informasi terkait norma kelompok yang kemudian dijadikan patokan pengembangan diri (Sedikides \& Gregg, 2008; Sedikides \& Strube, 1997).

Selain itu, gosip menyediakan informasi perbandingan sosial yang merefleksikan apakah diri kita melakukan hal yang lebih baik atau buruk dari norma kelompok. Jika individu merasa melakukan hal yang lebih baik daripada objek gosip, ia akan mengembangkan sikap promosi diri atau jika berperilaku lebih buruk daripada objek gosip, individu akan mengembangkan proteksi diri. Melakukan evaluasi diri melalui refleksi diri membuat individu mempunyai informasi, apakah mereka telah memenuhi representasi ideal diri mereka atau representasi sosial (Leary, 2007; Tracy \& Robins, 2004). 


\section{Pengembangan Diri $\quad($ Self- Improvement)}

Bagaimana mekanisme gossip sebagai pengembangan diri? Gosip mempunyai fungsi belajar sosial karena memberikan pelajaran dalam relasi sosial tentang bagaimana menjadi pribadi yang diterima atau menghindari secara spesifik hal-hal yang tidak disukai masyarakat (Baumeister et al., 2004). Memperoleh informasi evaluatif tentang orang lain dapat berpotensi untuk menavigasi kompetensi sosial yang dibutuhkan (Foster, 2004).

Dalam pandangan perspektif pengembangan diri, individu seharusnya lebih tertarik untuk menerima informasi yang positif, dibandingkan dengan yang negatif (Litman \& Pezzo, 2005) sehingga anggota kelompok yang dinilai melakukan sesuatu dengan lebih baik dapat berperan sebagai panutan (Yinon et al., 1989). Perbandingan sosial ke atas (upward comparison) dapat memotivasi individu untuk meningkatkan upaya mereka. Oleh karena itu, objek gosip, individu yang memiliki prestasi dapat menjadi inspirasi bagi individu tersebut untuk meningkatkan diri. Sebab, anggota masyarakat dapat mendeskripsikan gambaran ideal bagaimana seorang anggota kelompok dipuji.

\section{a) Promosi Diri (Self-Promotion) \\ Gosip juga dapat berfungsi sebagai} promosi diri bagi para pelakunya. Mekanisme promosi diri adalah dengan membuat perbandingan sosial ke bawah, yang secara inheren hadir dalam gosip negatif (Wert \& Salovey, 2004). Kebutuhan akan harga diri yang positif memotivasi orang untuk menarik kesimpulan yang menguntungkan tentang diri mereka sendiri. Orang melakukannya kapanpun mereka dapat menemukan pembenaran yang cukup untuk mendukung penilaian terhadap diri mereka sendiri (Kunda, 1990). Gosip merupakan informasi yang kaya dan mudah diakses serta dapat menjadi justifikasi konsep diri seseorang jika informasi tersebut dianggap mendukung konsep dirinya. Karena itu, kemungkinan besar, bagi para pelaku gosip, menerima gosip negatif mendorong keyakinan dan perasaan untuk mempromosikan diri individu tersebut bahwa mereka lebih baik daripada target gosip, apalagi jika gosip negatif mendukung relevansi konsep diri individu tersebut (Brown \& Brown, 2015).

Sebagaimana disebutkan sebelumnya, perbandingan ke bawah (downward comparison) adalah cara yang efektif untuk meningkatkan harga diri dan membuat diri sendiri merasa lebih baik dari orang lain (Wills, 1981). Hal ini disebabkan karena nilai promosi diri akan meningkat, semakin target gosip memiliki banyak kesamaan dengan dirinya, sebab kegagalan pesaing yang dalam kelas yang sama, secara tidak langsung mempromosikan konsep diri positif bagi pelaku gosip yang merasa lebih baik.

Teori ini didasarkan pada paradigma psikologi evolusi bahwa individu tertarik untuk menerima gosip negatif tentang rivalnya karena dapat mempromosikan nilai dirinya. Hal ini disebabkan informasi semacam itu merendahkan saingan dan mempromosikan diri (McAndrew, 2014; McAndrew et al., 2007). Jadi, gosip negatif membantu penerima mempromosikan diri sendiri dan mempertahankan pandangan diri yang positif. Selain itu, gosip negatif mungkin mempromosikan diri sendiri karena pengirim gosip memberi sinyal kepada penerima bahwa mereka layak menerima informasi sensitif seperti itu atau bahwa mereka lebih baik dari target (Bosson et al., 2006; Grosser et al., 2010). Oleh karena itu, gosip negatif dapat meningkatkan persepsi, status dan reputasi diri penerima dan pelaku gosip. Hal ini semakin menjustifikas i pembenaran diri dalam hierarki sosial (Ellwardt et al., 2012; Nevo et al., 1994). Sebagai hasil dari promosi diri melalui 
perbandingan ke bawah, individu mengalami peningkatan perasaan bangga (Wert \& Salovey, 2004). Kebanggaan menyampaikan kompetensi, kesuksesan, dan status muncul ketika orang memenuhi atau melampaui standar sosial (Tangney, 2003) atau mencapai hasil yang dihargai secara sosial (Leary, 2007). Penerima gosip negatif mungkin melihat aktivitas gosip negatif terhadap mereka yang digosipkan (target gosip) sebagai mekanisme mengecek kompetensi diri apakah mereka telah melampaui standar kompetensi sosial yang dapat memunculkan promosi diri dan emosi terkait kebanggaan.

\section{b) Proteksi Diri (Self Protection)}

Motif perlindungan diri menjadi menonjol ketika individu berusaha keras untuk membela diri dari konsep diri yang negatif. Perlindungan diri membantu individu menghindari situasi negatif, mencegah, dan membelokkan implikasi negatif informasi tersebut bagi dirinya (Sedikides \& Gregg, 2008). Gosip positif dan negatif dapat dipersepsi akan menimbulkan dua jenis ancaman yang berbeda untuk penerima. Pada tipe ancaman yang pertama, saat individu membuat perbandingan ke atas dengan orang lain yang serupa, dapat dipersepsi sebagai ancaman bagi posisi individu dalam hirarki sosial. Oleh karena itu, gosip positif, tentang prestasi individu dalam masyarakat, jika dipersepsi sebagai ancaman akan memunculkan perasaan rendah diri dan dapat mengaktifkan perlindungan diri (Wayment \& Taylor, 1995; Wert \& Salovey, 2004)

Di sisi lain, gosip negatif dapat bersifat mengancam jika lingkungan sosial berbicara negatif tentang orang lain yang memiliki karakteristik serupa dengan dirinya. Individu akan merasa khawatir, apakah gosip tersebut juga akan menimpa dirinya. Karenanya, gosip negatif dapat mengaktifkan mekanisme perlindungan diri bagi penerima karena penerima mungkin takut menjadi sasaran gosip negatif atas diri mereka sendiri karena proses refleksi sosial (Tesser, 1988). Pada dasarnya gosip negatif dapat merusak reputasi seseorang secara substansial, karena reputasi lebih mencerminkan kesan orang lain daripada informasi objektif tentang seseorang (Martinescu et al., 2014). Gosip positif dan negatif dapat membangkitkan perlindungan diri penerima gosip jika menimbulkan kekhawatiran. Prinsip bahwa hal-hal buruk lebih kuat dan merusak daripada yang baik (Baumeister et al., 2001) akan memprediksi hadirnya mekanisme perlindungan diri, terutama bagi para penerima gosip negatif, karena perlindungan diri adalah respon adaptif manusia bertahan dalam lingkungan sosial.

Mekanisme perlindungan diri kemungkinan besar terkait dengan ketakutan atau kecemasan sosial, yang muncul ketika individu meragukan kemampuan dirinya sendiri untuk menciptakan atau mempertahankan kesan yang baik di masyarakat (Leary, 2007). Perlindungan diri dikaitkan dengan rasa takut, terutama yang berkaitan dengan peristiwa negatif dengan efek samping yang tidak pasti terhadap individu penerima gosip (Frijda et al., 1989). Dengan demikian, individu yang menerima gosip negatif akan mengaktivasi perlindungan diri dan cenderung akan mengalami reaksi emosional seperti ketakutan karena merasa gambaran diri mereka telah negatif dan hal ini berimplikas i untuk reputasi mereka di masyarakat. Rasa takut adalah respon adaptif dan reaksi fungsional dalam situasi yang menimbulkan ancaman bagi individu (Öhman, 1993), karena ketakutan membantu individu untuk menilai situasi yang mengancam dan mempersiapkan perilaku protektif terhadap diri.

\section{Sinopsis}

Tilik adalah sebuah film pendek yang menggambarkan fenomena sosial yang 
jamak terjadi di masyarakat desa yaitu menjenguk seseorang secara bersamaan (rombongan). Film pendek ini dimulai dengan gambaran para ibu yang sedang menaiki truk dalam perjalanan untuk pergi menjenguk $\mathrm{Bu}$ Lurah yang sedang dirawat di rumah sakit. Kemudian, selama perjalanan di atas truk para ibu bercakap-cakap. Tokoh utama, yaitu Bu Tejo menjadi titik sentral percakapan, tidak berhenti mengumbar gosip tentang Dian, kembang desa yang cantik dan mandiri. Sepanjang perjalanan $\mathrm{Bu}$ Tejo menceritakan berbagai hal yang seolah bersifat fakta tentang Dian. Beberapa di antaranya adalah Dian digosipkan adalah calon menantu $\mathrm{Bu}$ Lurah sebab Dian yang mengantar $\mathrm{Bu}$ Lurah ke rumah sakit, Dian adalah perempuan yang tidak baik dan dapat meresahkan warga desa, terutama keutuhan rumah tangga. Premis ini muncul karena sifat ramah dan supel Dian sehingga mengembangkan asumsi bahwa Dian berpotensi untuk menggoda para lelaki yang sudah berkeluarga. Dasar yang dikemukakan oleh $\mathrm{Bu}$ Tejo berupa berita-berita di media sosial yang memuat tentang Dian. Kemudian, informasi dan berita yang disampaikan oleh $\mathrm{Bu}$ Tejo mendapat berbagai respon dari para ibu lainnya. Misalnya, terdapat tokoh bernama $\mathrm{Yu}$ Ning, yang kritis terhadap informasi yang disampaikan $\mathrm{Bu}$ Tejo. $\mathrm{Yu}$ Ning berpendapat bahwa tidak semua yang disampaikan $\mathrm{Bu}$ Tejo dapat serta merta diterima begitu saja. Bu Tejo pun tidak peduli, ia melanjutkan untuk menceritakan berbagai informasi negatif tentang Dian, apalagi terdapat salah seorang dari para Ibu yang menyokong. Klimaksnya, terjadi perang mulut antara Bu Tejo dengan Yu Ning yang pada dasarnya adalah keluarga Dian.

Dalam perjalanan, $\mathrm{Bu}$ Tejo dan beberapa ibu lainnya ingin ke kamar mandi, sehingga mereka menepi ke sebuah mushola di tengah sawah. Pada saat itu terjadi pengambilan adegan di mana $\mathrm{Yu}$ Ning ditelpon oleh Dian. Karena Yu Ning tidak memiliki ponsel pintar dan lupa melakukan isi ulang baterai ponselnya, akhirnya $\mathrm{Yu}$ Ning tidak dapat dihubungi. Dalam adegan ini, terlihat Gotrek, supir dan pemilik truk yang ditumpangi rombongan ibu-ibu ini memiliki rasa penasaran terhadap Dian sehingga istri Gotrek pun cemburu. Dalam proses percakapan itu, masuklah $\mathrm{Bu}$ Tejo yang memberi uang saku kepada Gotrek, padahal Gotrek telah diberi upah untuk mengantar mereka ke rumah sakit. Selama percakapan, tampak Yu Ning melancarkan kecurigaan kepada $\mathrm{Bu}$ Tejo bahwa ini adalah uang suap sebab Pak Tejo akan mencalonkan diri sebagai Lurah. Hal ini tidak ditolak oleh $\mathrm{Bu}$ Tejo secara terang-terangan.

Setelah perjalanan selesai, rombongan para ibu tersebut sampai di sebuah rumah sakit, kedatangan mereka disambut langsung oleh Dian dan Fikri. Meskipun telah bersusah payah berusaha untuk menjenguk, Dian menyayangkan kedatangan para tetangganya itu, sebab Bu Lurah masih berada di ruang perawatan intensif (ICU) dan belum boleh dijenguk oleh siapa pun. $\mathrm{Bu}$ Tejo yang mendengar informasi ini langsung membalas dengan cibiran kepada $\mathrm{Yu}$ Ning yang menjadi inisiator untuk menjenguk dengan terburu-buru bahkan menyewa truk sebab tidak ada lagi bus yang dapat disewa, padahal belum berbekal informasi akurat tentang kondisi Bu Lurah. Hal ini menjadi senjata $\mathrm{Bu}$ Tejo untuk menunjukkan bahwa ia yang lebih paham tentang cara mendapatkan informasi yang akurat. Karena kecewa tidak bisa menjenguk setelah bersusah payah menempuh perjalanan dengan berdiri, para ibu-ibu menghujat Yu Ning. Tetapi akhirnya, Bu Tejo menyarankan mereka untuk mampir ke pasar besar Beringharjo supaya tidak terlalu kecewa.

Pada akhir cerita, selepas rombongan ibu-ibu pulang dari rumah sakit lantaran tidak dapat menjenguk $\mathrm{Bu}$ Lurah, diceritakan bahwa Dian memasuki mobil sedan yang di 
dalamnya telah duduk seorang lelaki paruh baya yang dipanggil dengan sapaan "Mas". Kepada lelaki itu, Dian menumpahkan kegelisahan dan mengungkapkan, sebenarnya tak sanggup lagi menjalani hubungan sembunyi-sembunyi dan ingin menikah, juga kekhawatirannya, sanggupkah Fikri menerima kenyataan bila mengetahui ayahnya akan menikah dengannya. Artinya Dian pada dasarnya bukan berhubungan dengan Fikri, tetapi ayahnya.

\section{Karakter}

Terdapat beberapa karakter dalam film Tilik sebagai berikut.

\section{1) Bu Tejo (Pemeran Utama)}

$\mathrm{Bu}$ Tejo merupakan seorang ibu dengan taraf sosial ekonomi menengah setelah sebelumnya berada di level ekonomi bawah. Bu Tejo merupakan istri dari seorang pemborong. Melihat level ekonominya $\mathrm{Bu}$ Tejo memiliki kepercayaan diri yang lebih tinggi di antara para ibu-ibu tersebut.

\section{2) Yu Ning}

Yu Ning merupakan gambaran ibuibu yang tersulut emosi dengan gosip $\mathrm{Bu}$ Tejo. Yu Ning merupakan saudara Dian.

\section{3) Bu Tri}

Seorang Ibu dengan pawakan kurus yang mendukung $\mathrm{Bu}$ Tejo dan menambah-nambahkan informasi terkait Dian.

\section{4) Yu Sam}

Yu Sam memiliki karakter senang bergosip tetapi tidak sepercaya diri $\mathrm{Bu}$ Tejo dan $\mathrm{Bu}$ Tri.

\section{5) Dian}

Keponakan Yu Ning yang menjadi target dari gosip. Dian digambarkan sebagai sosok yang cantik dan pekerja keras namun belum menikah pada usia yang selayaknya menikah.

\section{6) Fikri}

Anak laki-laki $\mathrm{Bu}$ Lurah yang digambarkan memiliki perilaku yang kurang baik.

\section{7) Minto (ayah Fikri)}

Ayah dari Fikri dan suami dari Bu Lurah yang telah berpisah dari Ibu Lurah.

\section{8) Gotrek}

Gotrek, sopir truk yang bertugas mengantar gerombolan ibu-ibu dari desa ke rumah sakit untuk menjenguk $\mathrm{Bu}$ Lurah.

9) Yati

Istri Gotrek yang cemburu kepada Dian.

\section{Metode Penelitian}

Peneliti menggunakan pendekatan interpretasi Denzin (1989) yang menyatakan bahwa sebuah film adalah refleksi sebuah masyarakat baik secara tersirat maupun tersurat. Oleh karena itu, pendekatan Denzin mengatakan bahwa sebuah film dapat dianalisis menggunakan pemaknaan tersurat (realistic) dan tersirat (subversive) (Denzin, 2001a, 2001b; Flick et al., 2004). Pendekatan tersurat yang realistis artinya melihat film sebagai gambaran riil sebuah masyarakat, yang mana pemaknaannya dapat dilihat secara langsung melalui teks dan gambar yang disajikan dalam film tersebut. Interpretasi hanya untuk memvalidasi apa yang sudah disampaikan di film tersebut. Sementara, pemaknaan ulang peneliti terhadap ide utama pembuat film yang lebih dalam terhadap kata dan simbol merupakan pemaknaan tingkat subversive. Pada 
penelitian ini, peneliti menggunakan level analisis permukaan yaitu pemaknaan realistis. Kemudian, untuk melakukan analisis film, peneliti menggunakan empat proses yaitu; 1) melihat dan merasakan film sebagai sebuah keutuhan; 2) mencocokkan antara adegan dan dialog dengan pertanyaan penelitian; 3) melakukan mikroanalis is terstruktur terhadap setiap adegan dan dialog kunci, dan 4) menarik pola umum untuk menjawab pertanyaan penelitian (Denzin, 2001b). Peneliti telah melakukan semua tahapan tersebut.

\section{Hasil dan Pembahasan}

\section{Gosip sebagai Promosi dan Proteksi Diri}

Hasil telaah peneliti terhadap film Tilik menunjukkan bahwa gosip negatif lebih banyak mewarnai pembicaraan para ibu daripada gosip positif. Gosip negatif dalam film ini berfungsi sebagai promosi dan proteksi diri. Gosip negatif sebagai promosi diri akan mengantarkan para penggosip ke perasaan bangga. Sementara pada mekanisme proteksi diri akan mengantarkan kepada perasaan takut. Dinamika gosip dalam film Tilik digambarkan dalam bagan di bawah ini.

\section{a) Gosip Sebagai Promosi Diri}

Dalam film Tilik dapat dilihat bahwa para ibu yang melakukan perbandingan sosial ke atas (upward comparison) terhadap Dian. Dian sebagai objek Gosip memiliki beberapa kompetensi sosial berupa kecantikan, keramahan dan peningkatan harta yang tidak mereka miliki. Artinya perbandingan ke atas dilakukan dengan orang yang memiliki kelebihan daripada individu tersebut sehingga gosip ini, sehingga gosip terhadap kelebihan Dian dapat dikategorikan ke dalam gosip positif. Namun, apa-apa yang dimiliki Dian seperti pekerjaan, karakter ramah, dan peningkatan harta ternyata menjadi ancaman bagi para ibu tersebut. Hal ini dapat disebabkan gosip positif akan dipersepsi sebagai ancaman jika penerima gosip merasa rendah diri dengan kabar tersebut, sehingga dapat mengaktifkan perlindungan diri (Wayment \& Taylor, 1995; Wert \& Salovey, 2004).

Perlindungan diri ini adalah dengan melakukan peningkatan harga diri sehingga status perbandingan menjadi terbalik yaitu, pelaku gosip merendahkan objek gosip, sehingga terjadi perbandingan ke bawah. Misalnya, pada saat yang sama para Ibu menganggap pekerjaan Dian dianggap tidak pantas dan kurang terhormat. Pada saat ini, para ibu sedang menaikkan harga diri mereka bahwa pekerjaan mereka di desa lebih -

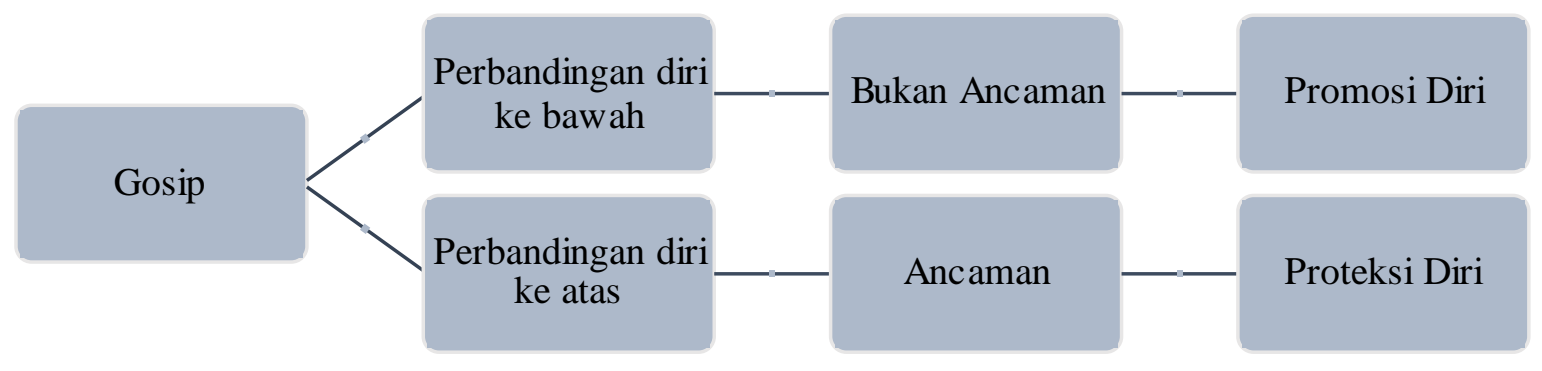

Bagan 1 Pola umum fungsi gosip sebagai promosi dan proteksi diri dalam film Tilik (2018) 
pantas daripada sang objek gosip. Kemudian, saat Dian dianggap mengalami peningkatan harta yang tidak wajar, hal ini menunjukkan bahwa para ibu sedang melakukan perbandingan dan merendahkan apa yang dicapai Dian. Hal ini mengandung perbandingan ke bawah yang bertujuan untuk meningkatkan harga diri. Mekanisme evaluasi diri dengan perbandingan ke bawah (downward comparison) menurut Wills (1981) adalah cara yang efektif untuk meningkatkan konsep diri sehingga membuat diri sendiri merasa lebih baik daripada orang lain. Hal ini membuat promosi diri akan meningkat. Sebagaimana cuplikan percakapan di bawah ini (yang telah diterjemahkan dari Bahasa Jawa ke Bahasa Indonesia).

\section{Gosip 1. Pekerjaan Dian}

Bu Tejo: Dian itu pekerjaannya apa ya? Kok ada yang pernah bilang, dia melakukan pekerjaan yang nggak pantas. Kan kasihan Bu Lurah, kalau Bu Lurah kalau sampai punya menantu kerjanya nggak benerkayak gitu. Ada yang pernah bilang kalau pekerjaannya Dia itu keluar masuk hotel gitu, lho, terus ke mall sama cowo segala. Kerjaan apa ya?

Yu Sam: Benarkah?

Yu Ning: Mungkin dia sedang menemani turis, siapa tahu?

\section{Gosip 2. Karakter Dian}

Yu Sam: Dian kan emang anaknya supel dan ramah, $B u$.

Bu Tejo: Itukan kalau di kampung kita. Nih, sekarang coba lihat deh, coba lihat. Ibu-lbu: Apa itu? - Teman-teman datang ke sini, lihat ini (melihat handphone)

Ibu-ibu: Masa kayak gitu sih fotonya? Dempet-dempetan.

Ibu-lbu: (muak) Semoga Tuhan mengampuninya (Semua orang bergosip)

Bu Tejo: Makanya punya HP itu jangan Cuma buat mejeng doang, tapi untuk mencari informasi, oke?
Ibu-ibu: ih, abis lihatfoto Dian, badanku jadi merinding deh.

\section{Gosip 3. Peningkatan Harta Dian}

Bu Tejo: Aku yakin dia punya banyak kerjaan sampingan, ya nggak? Nggak mungkin dia hanya mendapat satu pekerjaan. Tapi sampingannya ngapain, nggak tahu deh. Seorang perempuan, baru dapat pekerjaan, tiba-tiba kok uangnya sudah banyak. Kan jadi pertanyaan kalau kayak gitu, ya nggak? Yu Ning:Bu Tejo, kalaungomong jangan sembarangan.

Bu Tejo: Sembarang gimana lho, $Y u$ Ning? Satu kampung sudah membicarakan Dian. Di Facebook saja rame banget. Lihat aja komentarkomentar itu.

Ibu-Ibu: Udah pasti lah Dian jadi omongan, Bu.

Bu Tejo: Makanya, sekarang coba kalian pikirkan.Aku bukannya mau ngeremehin keluarga Dian, lho ya. Jelas dari kecil Dian itu ditinggal minggat sama bapaknya.Ibunya juga punya sawah cuma segitu doang. Makanya dia abis lulus SMA nggak kuliah, baru aja kerja. HPnya baru, motornya baru, iya kan? Uang dari mana coba? Barangbarangnya mahal-mahal semua lagi. Kayak aku nggak tahu merk aja.

Bu Tri: Yu Sam, Bu Tejo. Menurutku, kalau Dian kerjanya bener, nggak mungkin dia punya barang kayak gitu, ya nggak?

Ibu: Iya-iya bener itu.

Bu Tejo: Lho, iya bener.

Kemudian, Bu Tejo juga melakukan perbandingan ke bawah (downward comparison) dengan $\mathrm{Bu}$ Lurah. Hal ini membuat $\mathrm{Bu}$ Tejo tanpa disadari menonjolkan karakteristik diri yang tidak dimiliki oleh $\mathrm{Bu}$ Lurah, seperti kondisi $\mathrm{Bu}$ Tejo yang memiliki pasangan dan tidak memiliki masalah dengan anaknya tetapi $\mathrm{Bu}$ Lurah tidak. Dalam percakapan di bawah ini dapat dilihat bagaimana promosi diri (selfpromotion) menjadi bagian dari fungsi gosip. 
Bu Tejo: Lagian coba sekarang pada mikir deh, Bu Lurah kan sudah sering sakit-sakitan. Kasihan tho Bu Luran nih.Udah gitu, hidupnya sendiri. Punya anak satu aja nggak jelas begitu. Anak cowoknya gitu kan? Jadi, udah waktunya Bu Lurah itu istirahat.Kasihan tahu Bu Lurah, ya nggak?

Yu Ning: Maksudnya biar Pak Tejo yang nggantiin kan?

Bu Tejo: Bukan gitu, Cuma kasihan Bu Lurah. Beneran. Lagian kan sudah waktunya kampung kita punya lurah yang cekatan gitu, lho. Tapi nggak single. Kalau single buat ngurus hidupnya sendiri aja berat. Iya nggak?

Gotrek: Sekarang gini aja, Bu. Yang Jadi lurah Dian aja, gimana?

Bu Tri: Ya Allah, janganlah!

Pada beberapa dialog berikut dapat diamati bahwa gosip positif berubah menjadi gosip negatif sebab para pelaku gosip merasa terancam. Hal ini membuat gosip negatif yang memiliki fungsi promosi diri dengan memberikan informasi perbandingan yang lebih baik secara sosial kepada para penerima gosip, apabila perbandingan sosial mengarahkan kepada hasil yang menguntungkan penggosip maka individu yang mempromosikan diri akan merasa bangga. Menariknya, berlawanan dengan persepsi awam, mayoritas gosip negatif tidak dimaksudkan untuk menyakiti target, tetapi untuk menyenangkan penggosip dan penerima (Ben-Ze'ev, 1994).

\section{b) Gosip Sebagai Proteksi Diri}

Fungsi gosip kedua yang terlihat menonjol dalam film Tilik ini adalah fungsi proteksi diri. Sebab, Bu Tejo dan Bu Tri menyebutkan secara jelas bahwa tujuan mereka mencari informasi tentang Dian adalah untuk melakukan melindungi keluarga mereka apabila Dian memang benar wanita yang senang menjalin relasi dengan suami orang.
Sedikides dan Gregg (2008) menjelaskan bahwa individu akan mencoba menghindari segala kemungkinan buruk yang akan menimpa dirinya. Sebab, hal-hal buruk lebih menakutkan daripada hal baik (Baumeister, Bratslavsky, Finkenauer, \& Vohs, 2001) apalagi jika efek samping dari hal negatif itu belum dapat ditanggulangi (Frijda, Kuipers, \& Ter Schure, 1989). Percakapan di bawah ini menjelaskan bagaimana kekhawatiran mengaktivasi proteksi diri.

Yu Ning: Bu Tejo, nih. Ngomongin Dian terus nggak ada bosen-bosennya, ya?

Bu Tejo: Ya itu salah Dian. Diannya aja tuh yang aneh-aneh. Orang udah seumur begitu kok belum menikah? Tementemennya aja udah nikah semua.

Yu Ning: Lha, kalau semisal dia pengen fokus sama karirnya bagaimana? Kan kita nggak tahu keadaan Dian sebenarnya kayak gimana.

Bu Tejo: Kayak hidupnya punya kariraja.. Yu Ning: Mbok ya sudah, jangan nyebar fitnah.

Ibu-ibu: Bener itu, kata Yu Ning. Bu Tejo, fitnah itu lebih kejam daripada pembunuhan.

Bu Tejo: Aku itu nggak memfitnah, aku ini cuma hati-hati aja. Jaga-jaga kalau Dian itu sebenarnya emang perempuan nakal. Tukang menggoda suami kita.

Bu Tri: Kalau begitu, ya bisa jadi bener $B u$.

Dalam hal ini, Bu Tejo menjelaskan ketakutannya jika suaminya memiliki hubungan dengan wanita lain dan sikap ini diafirmasi oleh para Ibu lainnya. Suami memiliki hubungan dengan wanita lain dianggap sebagai kemungkinan buruk yang akan menimpa mereka. Hal ini wajar dilakukan individu yang merasa di bawah ancaman, sebab rasa takut adalah respon alamiah dan naluriah manusia (Öhman, 1993). Hal ini dapat dilihat dari dua contoh percakapan yang disertakan dalam artikel ini. 
Bu Tejo: Yu Sam, sekarang aku mau tanya, dari tadi aku tanya-tanya soal Dian. Yu Ning selalu ngeyel.

Yu Sam: he eh (mengiyakan)

Bu Tejo: Kalau aku memberi informasi soal Dian, apa aku keliru?

Bu Tri: Tidak Bu Tejo. Anda itu bener kok, kalau hidupnya Dian itu rusak. Kan itu masalahnya dia sendiri. Yang penting nggak merusak keluarga kita.

Yu Ning: Lha iya Bu Tri, kalau informasi itu benar. Kalau salah?

Percakapan di atas menggambarkan bahwa karakter Dian menimbulkan kekhawatiran sehingga para ibu bergosip dengan tujuan untuk melakukan perlindungan diri. Perbandingan sosial memungkinkan individu menarik analogi antara dirinya dan orang lain. Jika mereka merasa perbandingan sosial tidak menguntungkan individu tersebut, sosok objek gosip akan membuat orang merasa khawatir reputasi mereka akan terancam. Dalam konteks film Tilik ini reputasi keluarga adalah hal yang penting. Penelitian ini menunjukkan bahwa emosi takut meningkatkan pemrosesan informasi yang sistematis, sehingga individu berusaha melakukan segala usaha untuk memprediksi secara terstruktur meskipun melalui informasi yang belum tentu benar (Baas, De Dreu, \& Nijstad, 2012). Hal ini menunjukkan bahwa ketakutan merupakan respons adaptif terhadap ancaman gosip negatif. Ketakutan mendorong individu untuk mengambil tindakan untuk menjaga integritas sistem diri mereka dan untuk mempertahankan diri terhadap kemungkinan hasil negatif (Green, Sedikides, Pinter, \& Van Tongeren, 2009).

\section{Simpulan}

Film Tilik menyuguhkan sebuah fenomena gosip yang berfungsi sebagai promosi dan proteksi diri, baik secara langsung maupun tidak langsung. Apabila gosip dianggap menguntungkan diri melalui perbandingan ke bawah individu akan mempunyai kesempatan untuk menaikkan gambaran diri (promosi diri) sebaliknya apabila gosip dianggap mengancam maka akan mengaktivasi perlindungan diri. Selain itu, promosi diri melibatkan emosi bangga, sementara proteksi diri melibatkan emosi takut. Hasil penelitian ini menjadi petunjuk bagaimana seseorang mengolah gosip sebagai sarana evaluasi diri dengan lingkungannya.

\section{Daftar Pustaka}

Baumeister, R. F., Bratslavsky, E., Finkenauer, C., \& Vohs, K. D. (2001). $\mathrm{Bad}$ is Stronger than Good. Review of General Psychology, 5(4), 323-370. https://doi.org/10.1037/10892680.5.4.323

Baumeister, R. F., Zhang, L., \& Vohs, K. D. (2004). Gossip as Cultural Learning: Review of General Psychology. https://journals.sagepub.com/doi/abs/10. 1037/1089-2680.8.2.111

Beersma, B., \& Van Kleef, G. A. (2011). How the Grapevine Keeps You in Line: Gossip Increases Contributions to the Group. Social Psychological and Personality Science, 2(6), 642-649. https://doi.org/10.1177/1948550611405 073

Bosson, J. K., Johnson, A. B., Niederhoffer, K., \& Swann Jr., W. B. (2006).

Interpersonal chemistry through negativity: Bonding by sharing negative attitudes about others. Personal Relationships, 13(2), 135-150. https://doi.org/10.1111/j.14756811.2006.00109.x

Brown, M. A., \& Brown, J. D. (2015). Selfenhancement biases, self-esteem, and ideal mate preferences. Personality and Individual Differences, 74, 61-65. https://doi.org/10.1016/j.paid.2014.09.0 39 
Denzin, N. K. (1989). Interpretive interactionism. Sage Publications, Inc.

Denzin, N. K. (2001a). The reflexive interview and a performative social science. Qualitative Research, 1(1), 2346.

https://doi.org/10.1177/1468794101001 00102

Denzin, N. K. (2001b). Interpretive Interactionism. SAGE.

Dunbar, R. I. M. (2004). Gossip in Evolutionary Perspective. Review of General Psychology, 8(2), 100-110. https://doi.org/10.1037/10892680.8.2.100

Ellwardt, L., Labianca, G. (Joe), \& Wittek, R. (2012). Who are the objects of positive and negative gossip at work?: A social network perspective on workplace gossip. Social Networks, 34(2), 193-205.

https://doi.org/10.1016/j.socnet.2011.11 .003

Feinberg, M., Willer, R., Stellar, J., \& Keltner, D. (2012). The virtues of gossip: Reputational information sharing as prosocial behavior. Journal of Personality and Social Psychology, 102(5), 1015-1030. https://doi.org/10.1037/a0026650

Festinger, L. (1954). A Theory of Social Comparison Processes. Human Relations, 7(2), 117-140. https://doi.org/10.1177/0018726754007 00202

Flick, U., Kardoff, E. von, \& Steinke, I. (2004). A Companion to Qualitative Research. SAGE.

Foster, E. K. (2004). Research on Gossip: Taxonomy, Methods, and Future Directions. Review of General Psychology, 8(2), 78-99. https://doi.org/10.1037/10892680.8.2.78

Frijda, N., Kuipers, P., \& Schure, E. ter. (1989). Relations Among Emotion,
Appraisal, and Emotional Action Readiness. Journal of Personality and Social Psychology, 57(2), 212-228.

Grosser, T. J., Lopez-Kidwell, V., \& Labianca, G. (2010). A Social Network Analysis of Positive and Negative Gossip in Organizational Life. Group \& Organization Management, 35(2), 177212. https://doi.org/10.1177/1059601109360 391

Jones, D. (1980). Gossip: Notes on women's oral culture. Women's Studies International Quarterly, 3(2), 193-198. https://doi.org/10.1016/S01480685(80)92155-7

Kintoko, W. I. (2020). Setelah 16 Hari Diunggah di Kanal YouTube Ravacana Films, Film 'Tilik' Telah Ditonton 20 Juta Views. Warta Kota. https://wartakota.tribunnews.com/20 20/09/01/setelah-16-hari-diunggahdi-kanal-youtube-ravacana-filmsfilm-tilik-te lah-ditonton-20-jutaviews

Kniffin, K. M., \& Wilson, D. S. (2005).

Utilities of Gossip across

Organizational Levels: Multilevel Selection, Free-Riders, and Teams. Human Nature, 16(3), 278-292. https://doi.org/10.1007/s12110-0051011-6

Kunda, Z. (1990). The case for motivated reasoning. PsychologicalBulletin, 108(3), 480-498.

https://doi.org/10.1037/00332909.108.3.480

Leary, M. R. (2007). Motivational and Emotional Aspects of the Self. Annual Review of Psychology, 58(1), 317-344. https://doi.org/10.1146/annurev.ps ych.5 8.110405.085658

Litman, J. A., \& Pezzo, M. V. (2005). Individual differences in attitudes towards gossip. Personality and Individual Differences, 38(4), 963-980. 
https://doi.org/10.1016/j.paid. 2004.09.0 03

Martinescu, E., Janssen, O., \& Nijstad, B. A. (2014). Tell Me the Gossip: The SelfEvaluative Function of Receiving Gossip About Others. Personality and Social Psychology Bulletin, 40(12), 1668-1680.

https $/ /$ doi.org/10.1177/0146167214554 916

McAndrew, F. T. (2014). The "sword of a woman": Gossip and female aggression. Aggression and Violent Behavior, 19(3), 196-199.

https://doi.org/10.1016/j.avb.2014.04.00 6

McAndrew, F. T., Bell, E. K., \& Garcia, C. M. (2007). Who Do We Tell and Whom Do We Tell On? Gossip as a Strategy for Status Enhancement1. Journal of Applied Social Psychology, 37(7), 1562-1577.

https://doi.org/10.1111/j.15591816.2007.00227.x

Merry, S. E. (1984). 10-Rethinking Gossip and Scandal**I am grateful to the Center for Studies of Metropolitan Problems of the National Institute of Mental Health for support under grant no. $1 \mathrm{~F} 31 \mathrm{MH}$ 05088-01 for the research described in this chapter. In D. Black (Ed.), Toward a General Theory of Social Control (pp. 271-302).

Academic Press. https://doi.org/10.1016/B978-0-12102801-5.50016-9

Nevo, O., Nevo, B., \& Derech-Zehavi, A. (1994). The tendency of gossip as a psychological disposition: Constructing a measure and validating it. In Good gossip (pp. 180-189). University Press of Kansas.

Öhman, A. (1993). Fear and anxiety as emotional phenomena: Clinical phenomenology, evolutionary perspectives, and information- processing mechanisms. In Handbook of emotions (pp. 511-536). The Guilford Press.

Pyszczynski, T., Greenberg, J., Solomon, S., Arndt, J., \& Schimel, J. (2004). Converging Toward an Integrated Theory of Self-Esteem: Reply to Crocker and Nuer (2004), Ryan and Deci (2004), and Leary (2004). Psychological Bulletin, 130(3), 483488. https://doi.org/10.1037/00332909.130.3.483

Sedikides, C., \& Gregg, A. P. (2008). SelfEnhancement: Food for Thought. Perspectives on Psychological Science, 3(2), 102-116. https://doi.org/10.1111/j.17456916.2008.00068.x

Sedikides, C., \& Skowronski, J. J. (2000). On the evolutionary functions of the symbolic self: The emergence of selfevaluation motives. In Psychological perspectives on self and identity (pp. 91-117). American Psychological Association. https://doi.org/10.1037/10357-004

Sedikides, C., \& Strube, M. J. (1997). Self evaluation: To thine own self be good, to thine own self be sure, to thine own self be true, and to thine own self be better. In Advances in experimental social psychology, Vol. 29 (pp. 209269). Academic Press. https://doi.org/10.1016/S00652601(08)60018-0

Sommerfeld, R. D., Krambeck, H.-J., Semmann, D., \& Milinski, M. (2007). Gossip as an alternative for direct observation in games of indirect reciprocity. Proceedings of the National Academy of Sciences of the United States of America, 104(44), 1743517440. https://doi.org/10.1073/pnas.070459810 4 
Suls, J. M. (1977). Gossip as social comparison. Journal of Communication, 27(1), 164-168.

https://doi.org/10.1111/j.1460-

2466.1977.tb01812.x

Tangney, J. P. (2003). Self-relevant emotions. In Handbook of self and identity (pp. 384-400). The Guilford Press.

Tesser, A. (1988). Toward a Self-Evaluation Maintenance Model of Social Behavior. In L. Berkowitz (Ed.), Advances in Experimental Social Psychology (Vol. 21, pp. 181-227). Academic Press. https://doi.org/10.1016/S0065-2601 (08)60227-0

Tracy, J. L., \& Robins, R. W. (2004).

TARGET ARTICLE: 'Putting the Self Into Self-Conscious Emotions: A Theoretical Model'. Psychological Inquiry, 15(2), 103-125.

https://doi.org/10.1207/s15327965pli15 02_01
Wayment, H. A., \& Taylor, S. E. (1995). Self-evaluation processes: Motives, information use, and self-esteem. Journal of Personality, 63(4), 729-757. https://doi.org/10.1111/j.14676494.1995.tb00315.x

Wert, S. R., \& Salovey, P. (2004). A Social Comparison Account of Gossip. Review of General Psychology, 8(2), 122-137. https://doi.org/10.1037/10892680.8.2.122

Wills, T. A. (1981). Downward comparison principles in social psychology. Psychological Bulletin, 90(2), 245-271. https://doi.org/10.1037/00332909.90.2.245

Yinon, Y., Bizman, A., \& Yagil, D. (1989). Self-Evaluation Maintenance and the Motivation to Interact. Journal of Social and Personal Relationships, 6(4), 475486. https://doi.org/10.1177/0265407589064 006 